\title{
IDEOLOGI SEBAGAI RAMALAN MASA DEPAN: HAKIKAT IDEOLOGI MENURUT KARL MANNHEIM
}

\section{IDEOLOGY AS A VISION OF THE FUTURE: THE NATURE OF IDEOLOGY ACCORDING TO KARL MANNHEIM}

\author{
Reno Wikandaru ${ }^{1}$ \\ Universitas Gadjah Mada \\ Shely Cathrin ${ }^{2}$ \\ Universitas Negeri Yogyakarta
}

renowikandaru@ugm.ac.id

shelycathrin@uny.ac.id

\begin{abstract}
ABSTRAK: Tujuan dari penelitian ini adalah untuk mendeskripsikan hakikat ideologi menurut Karl Mannheim serta menganalisis landasan ontologis, epistemologis, dan aksiologis yang mendasari pemikirannya. Penelitian ini adalah penelitian pustaka (library research), dengan memakai beberapa unsur metodis, yakni deskripsi, historis, analitika bahasa, abstraksi, hermeneutika, dan heuristika. Hasil penelitian menunjukkan bahwa menurut Mannheim, ideologi mengacu pada sebuah kondisi yang belum atau tidak teriadi, dalam arti tidak ada dalam kenyataan. Ideologi berarti ramalan tentang masa depan berdasarkan pada sistem yang saat ini sedang berlaku. Selain itu, Mannheim juga membedakan dua macam ideologi, yaitu ideologi partikular dan ideologi total. Ideologi partikular adalah ideologi yang dipahami secara psikologis oleh seorang individu; sedangkan ideologi total adalah ideologi yang dimiliki oleh suatu komunitas sehingga sangat dekat dengan pengertian welstanchauung. Dari perspektif ontologis, dalam pemikiran Karl Mannheim tentang ideologi terkandung asumsi adanya realitas objektif. Dari perspektif epistemologi, pemikiran Karl Mannheim tentang ideologi menyiratkan pemikiran subjektivisme epistemologis. Dari perspektif aksiologis, kekuasaan yang berkaitan dengan politik masih menduduki hierarki yang tertinggi dalam ideologi.
\end{abstract}

Kata Kunci: ideologi, Karl Mannheim, Ramalan, Masa Depan, Utopia

ABSTRACT: This study aims to describe the nature of ideology according to Karl Mannheim and to analyze the ontological, epistemological, and axiological foundations that underlie his thinking. This research is library research, using several methodical elements, namely description, history, language analysis, abstraction, hermeneutics, and heuristics. The results show that according to Mannheim, ideology refers to a condition that has not or did not occur, in the sense that it does not exist. Ideology means predictions about the future based on the current system. In addition, Mannheim also distinguishes two kinds of ideology, namely the particular ideology and the total ideology. A particular ideology is an ideology that is psychologically understood by an individual; while the total ideology is an ideology that is owned by a community so that it is very close to the notion of welstanchauung. From an ontological perspective, Karl Mannheim's thought about ideology contains the assumption of an objective reality. From an epistemological perspective, Karl Mannheim's thought about ideology implies epistemological subjectivism. From an axiological perspective, power related to politics still occupies the highest hierarchy in ideology.

Keyword: ideology, Karl Mannheim, Vision, Future, Utopia

\section{A. PENDAHULUAN}

Perkembangan teknologi, khususnya perkembangan teknologi komunikasi telah membawa dampak yang besar dalam kehidupan umat manusia, tidak terkecuali dalam bidang politik. Marshall McLuhan seorang filsuf komunikasi era kontemporer sudah 
memprediksi hal ini dengan sebuah situasi yang disebut dengan global citizen. ${ }^{1}$ Istilah ini mengacu pada satu kondisi ketika setiap manusia di seluruh dunia telah melebur identitasnya menjadi satu yaitu sebagai warga global atau global citizen. Pandangan ini mengasumsikan lunturnya sekat-sekat wilayah, bangsa, negara, dan ikatan primordial lain yang dimiliki oleh manusia. Seluruh umat manusia dianggap memiliki satu identitas yang sama, yakni sebagai warga negara global. Situasi ini menurut McLuhan muncul karena perkembangan di bidang teknologi informasi yang mempertemukan seluruh umat manusia pada satu 'ruang' yang sama, yang disebut dengan internet. Saat ini para pengguna internet tidak disebut dengan namanya, asal negaranya, asal daerahnya, dan berbagai identitas personal lainnya. Para pengguna internet ini disebut dengan istilah yang sama, yaitu netizen atau internet citizen. Sebutan ini menyiratkan adanya penyamaan identitas para pengguna teknologi informasi saat ini. Terlepas dari asal negaranya, para pengguna internet disebut dengan sebutan seragam: netizen. ${ }^{2}$

Lunturnya sekat-sekat negara dan bangsa pada satu sisi membawa sisi positif karena setiap manusia akan merasa memiliki "rumah" di mana pun berada. Seluruh tempat terasa seperti "rumah" selama manusia memiliki konektivitas internet. Meskipun sedang berada di luar negara, selama masih bisa berkomunikasi dengan keluarga, menonton saluran YouTube yang sama, saling bertegur sapa dengan teman-teman yang sama di Instagram, maka rasanya masih seperti di rumah. Sisi negatifnya, kondisi ini mengancam kedaulatan negara dan memudarkan identitas kebangsaan seperti yang ditulis oleh Christian Fuchs dalam artikelnya yang berjudul Nationalism on the Internet. ${ }^{3}$ Nilai-nilai dari budaya luar yang terkadang bertentangan dengan nilai-nilai budaya setempat masuk dengan bebasnya.

Pada bidang politik, situasi ini menimbulkan ancaman yang serius. Peran ideologi dalam kehidupan kebangsaan mulai dipertanyakan kembali sebab ikatan-ikatan ideologi mulai memudar. Manusia tidak lagi peduli dengan ideologi yang dianut oleh negara. Ia merasa telah menjadi warga negara global, dengan aturan-aturan yang bersifat global pula. Situasi ini seakan diperparah dengan munculnya kajian-kajian yang menganggap

\footnotetext{
${ }^{1}$ Malcolm Griffith, Earl Seidman, and Marshall McLuhan, "Understanding Media: The Extensions of Man," College Composition and Communication, 1968, https://doi.org/10.2307/355246.

2 Rebecca MacKinnon, “The Netizen,” Development 55, no. 2 (June 7, 2012): 201-4, https://doi.org/10.1057/dev.2012.5.

${ }^{3}$ Christian Fuchs, Nationalism on the Internet (Routledge, 2019), https://doi.org/10.4324/9780429343476.
} 
berakhirnya peran ideologi dalam kehidupan manusia kontemporer, misalnya seperti yang disampaikan oleh Daniel Bell. ${ }^{4}$

Absennya kajian tentang ideologi menjadi bahaya tersendiri karena setidaknya dua alasan. Pertama, lunturnya pemahaman tentang ideologi berdampak pada matinya nalar kritis tentang ideologi itu sendiri. Sejak isu tentang global citizen atau netizen muncul, wacana tentang ideologi juga memudar. Beberapa penulis membuat pernyataan bahwa ideologi telah mati. ${ }^{5}$ Membicarakan ideologi dianggap tidak lagi relevan. Padahal munculnya kritik terhadap ideologi berarti memunculkan ideologi baru. Setiap pembicaraan yang menafikan ideologi, sebenarnya sedang membicarakan ideologi dalam bentuk yang lain. Kedua, absennya kajian tentang ideologi juga dapat berakibat pada lunturnya posisi penting ideologi bagi sebuah negara. Situasi ini bisa menjadi masalah karena sebuah ideologi ibarat menjadi visi sebuah negara. Absennya kajian tentang ideologi dapat meruntuhkan kesadaran generasi terhadap peran penting ideologi di dalam kehidupan politik. Dalam konteks Indonesia misalnya, ketika pengetahuan tentang ideologi nasional Pancasila ini tidak diwariskan dari generasi ke generasi, sangat mungkin terjadi pendangkalan pemahaman tentang ideologi yang berdampak pada sikap skeptisisme terhadap ideologi itu sendiri.

Ideologi sekeras apapun manusia berusaha menghilangkannya, ia tidak akan pernah hilang dari pemikiran manusia. Situasi ini mirip dengan kritik terhadap metafisika. ${ }^{6}$ Alasannya karena setiap usaha untuk menyingkirkan ideologi sesungguhnya sedang menawarkan ideologi yang baru pada saat yang sama. Pemikiran tentang ideologi oleh karenanya perlu diolah kembali. Salah satu pemikiran tentang ideologi yang dapat dijadikan sebagai alternatif pemikiran untuk memahami ideologi adalah pemikiran ideologi menurut Karl Mannheim, seorang tokoh yang berasal dari Hungaria dan menjadi salah satu tokoh penting dalam bidang sosiologi pengetahuan. Berdasarkan latar belakang di atas, tulisan ini bertujuan untuk mendeskripsikan hakikat ideologi menurut Karl Mannheim serta menganalisis landasan ontologis, epistemologis, dan aksiologis yang mendasari pemikiran Mannheim tentang ideologi. Analisis filosofis tentang hakikat ideologi dalam pemikiran Mannheim akan membuka perspektif baru dalam diskursus

\footnotetext{
${ }^{4}$ Nuswantoro and Amien Wangsitalaja, Daniel Bell: Matinya Ideologi (Magelang: Indonesia Tera, 2001).

${ }^{5}$ Nuswantoro and Wangsitalaja.

${ }^{6}$ Frederick Sontag, Problems of Metaphysics (Scranton, Chandler Pub. Co., 1970).
} 
ideologi sebagai satu aspek yang berperan penting di dalam mengonstruksi pemahaman manusia tentang realitas.

Penelitian-penelitian yang mengkaji tentang hakikat ideologi menurut Karl Mannheim tergolong jarang dilakukan, khususnya yang membahas landasan filosofis dari pemikiran Karl Mannheim. Beberapa hasil penelitian yang ditemukan antara lain adalah penelitian berjudul: Utopia or ideology: Karl Mannheim and the place of theory, yang ditulis oleh Ackroyd. Artikel ini diterbitkan di The Sociological Review pada tahun 2002 dan membahas tentang teori Mannheim seputar ideologi dan utopia sebagai salah satu bagian penting dari pemikiran sosiologi pengetahuan yang dikembangkannya. ${ }^{7}$ Temuan yang lain dapat dilihat dari tulisan berjudul Ideology and Utopia in Karl Mannheim: Revisiting the Origins of the Sociology of Self-Knowledge for an Exploratory Framework. Tulisan ini ditulis oleh Tamdgidi dan dipublikasikan di Human Architecture: Journal of the Sociology tahun 2020. Berbeda dengan artikel pertama yang membahas tentang pemikiran ideologi dan utopia Karl Mannheim, artikel yang kedua ini membahas tentang pemikiran Mannheim dari sudut pandang sosiologi. ${ }^{8}$

Beberapa penelitian yang membahas tentang pemikiran Karl Mannheim di atas memiliki kekurangan yang mendasar, yaitu tidak adanya kajian temuan tentang hakikat ideologi serta analisis landasan filosofis yang melatarbelakangi pemikiran ideologi Karl Mannheim. Penelitian ini ingin menunjukkan perspektif baru di dalam memahami pemikiran Karl Mannheim tersebut, dengan memberikan sudut pandang filosofis khususnya landasan ontologis, epistemologis, dan aksiologis dari pemikiran Karl Mannheim tentang ideologi. Karl Mannheim (1893-1947) sebenarnya bukanlah tokoh di bidang filsafat politik. Mannheim adalah tokoh bidang ilmu sosiologi yang memperkenalkan sebuah bidang kajian baru dalam bidang sosiologi dan epistemologi, yaitu sosiologi pengetahuan. Pemikirannya tentang ideologi muncul manakala Mannheim membicarakan tentang perbedaan ranah realitas dan ideologi, yang kemudian dibahas

\footnotetext{
7 S Ackroyd, "Utopia or Ideology: Karl Mannheim and the Place of Theory," The Sociological Review (journals.sagepub.com, 2002), https://doi.org/10.1111/j.1467-954X.2002.tb03578.x.

${ }^{8}$ M H Tamdgidi, "Ideology and Utopia in Karl Mannheim: Revisiting the Origins of the Sociology of Self-Knowledge for an Exploratory Framework.," in Human Architecture: Journal of the Sociology of Self-Knowledge (Okcir Press, 2020),

http://search.ebscohost.com/login.aspx?direct=true\%5C\&profile=ehost\%5C\&scope=site\%5C\&authtype= crawler\%5C\&jrnl=15405699\%5C\&AN=146868737\%5C\&h=S4YD54vEJ8FxzzDk37CIHdzOcnyT7TU \%2FNkrC5wObVAGiF\%2FSLzSiziMOSJuhq6Y8NsNuRNTumnZgZYp\%2BvzVxI3w\%3D\%3D\%5C\&c $\mathrm{rl}=\mathrm{c}$.
} 
bersama-sama dengan utopia, sebagaimana tertulis dalam bukunya Ideology and Utopia, An Introduction to the Sociology of Knowledge.

Melihat latar belakang keilmuan Karl Mannheim di atas, penelitian ini oleh karenanya tidak membahas pemikiran Karl Mannheim tentang sosiologi pengetahuan secara total. Sebaliknya, peneliti memfokuskan perhatian pada pembahasan tentang pemikiran Karl Mannheim tentang ideologi, sebagai bagian dari pemikirannya tentang sosiologi pengetahuan, dan kemudian menyelidiki basis filsafat yang melatarbelakangi pemikiran tersebut. Melalui cara seperti ini, harapannya pembahasan tentang ideologi dalam perspektif Karl Mannheim ini tetap berada pada koridor kajian filsafat. Perbedaan penelitian ini dengan beberapa artikel tersebut, adalah bahwa penelitian ini menggunakan sudut pandang atau objek formal ilmu filsafat. Secara spesifik, penelitian ini di samping menyelidiki hakikat ideologi menurut Mannheim, juga berusaha menyelidiki pemikiran filsafat yang melatarbelakangi pemikiran Mannheim tentang ideologi tersebut. Hal ini berbeda dengan beberapa artikel tentang pemikiran ideologi menurut Karl Mannheim yang dipaparkan di atas.

\section{B. METODE PENELITIAN}

Penelitian ini merupakan penelitian pustaka (library research) yang menggunakan model penelitian tentang pemikiran seorang tokoh atau filsuf. Jalannya penelitian terdiri atas tiga tahapan, yaitu pengumpulan data, pengolahan data, dan penyajian hasil penelitian. Objek material dalam penelitian ini adalah pemikiran seorang filsuf, yaitu Karl Mannheim, sedangkan objek formal yang digunakan sebagai alat analisis adalah filsafat, yang mengerucut pada bidang filsafat politik khususnya ideologi. Buku yang menjadi data primer dalam penelitian ini adalah buku Karl Mannheim yang berjudul "Ideology and Utopia: An Introduction to the Sociology of Knowledge", yang telah diterjemahkan ke dalam bahasa Indonesia dengan judul "Ideologi dan Utopia: Menyingkap Kaitan Pikiran dan Politik" yang diterbitkan oleh Penerbit Kanisius, Yogyakarta, tahun 1991. Kepustakaan yang menjadi data skunder dalam penelitian ini adalah buku, jurnal, majalah, surat kabar, artikel, maupun tulisan dari sumber lain hasil penelusuran pustaka yang mengkaji pemikiran Karl Mannheim sebagai objek material maupun mengkaji ideologi sebagai objek formal penelitian. Analisis data dalam 
penelitian ini menggunakan beberapa unsur metodis penelitian filosofis, antara lain deskripsi, historis, analitika bahasa, hermenutika, dan heuristika.

\section{HASIL DAN PEMBAHASAN}

\section{Diskursus tentang Ideologi dalam Filsafat Politik}

Ideologi merupakan salah satu tema utama dalam kajian filsafat politik. Penelusuran terhadap makna ideologi dapat dilihat dari tiga sudut pandang, yaitu etimologis, historis, dan terminologis. Secara etimologis, atau dari segi asal kata, Lorens Bagus, dalam Kamus Filsafat, mengemukakan bahwa istilah "ideologi” berasal dari bahasa Yunani "idea" yang berarti "ide" atau "gagasan" dan "logos" yang berarti "studi tentang", "ilmu", atau "pengetahuan tentang". Berdasarkan asal katanya tersebut, secara harfiah dan sebagaimana digunakan dalam metafisika klasik, ideologi merupakan ilmu pengetahuan tentang ide-ide, atau studi tentang asal-usul ide. ${ }^{9}$

Penelusuran etimologis yang hampir sama juga dikemukakan oleh Kaelan. Menurut Kaelan, kata "idea" berasal dari kata bahasa Yunani "eidos" yang artinya "bentuk". Di samping itu ada kata "idein" yang artinya "melihat". Secara harfiah, ideologi berarti ilmu pengetahuan tentang ide-ide (the science of ideas), atau ajaran tentang pengertian-pengertian dasar. "Idea" dalam pengertian sehari-hari disamakan artinya dengan "cita-cita". Cita-cita yang dimaksud adalah cita-cita yang bersifat tetap, yang harus dicapai, sehingga cita-cita yang bersifat tetap tersebut sekaligus merupakan dasar, pandangan, atau faham. Dasar dan cita-cita pada hakikatnya merupakan satu kesatuan. Dasar ditetapkan karena ada cita-cita yang mau dicapai; sebaliknya, cita-cita ditetapkan berdasarkan atas suatu landasan, asa atau dasar yang telah ditetapkan pula. Berdasarkan pengertian di atas, ideologi mencakup pengertian tentang idea-idea, pengertian dasar, gagasan-gagasan, dan cita-cita. ${ }^{10}$

Dilihat dari sudut pandang kedua, yaitu sudut pandang historis, dapat dilihat bahwa istilah "ideologi" adalah istilah yang memiliki sejarah panjang. Apabila ditelusuri dari segi sejarah, istilah ide pertama kali dipakai dan dikemukakan oleh seorang berkebangsaan Perancis, yaitu Destutt de Tracy pada tahun 1796. Seperti halnya Leibnitz, de Tracy mempunyai cita-cita untuk membangun suatu sistem

\footnotetext{
${ }^{9}$ Lorens Bagus, Kamus Filsafat (Jakarta: Gramedia Pustaka Utama, 2000).

${ }^{10}$ Kaelan, Negara Kebangsaan Pancasila: Historis, Kultural, Filosofis, Yuridis, Dan Aktualisasinya (Yogyakarta: Paradigma, 2013).
} 
pengetahuan. Apabila Leibniz menyebutkan impian-impiannya sebagai "one great system of truth", yaitu tergabungnya segala cabang ilmu dan segala kebenaran ilmu, maka de Tracy menyebutkan ideologie, yaitu science of ideas, suatu program yang diharapkan dapat membawa perubahan institusional dalam masyarakat Perancis. ${ }^{11}$ Destutt de Tracy memperkenalkan istilah ideologiste untuk mencirikan filsuf, yang seperti dirinya sendiri, mengembalikan ide-ide kepada kesan-kesan tempat asal ideide. Napoleon yang menganggap Destutt de Tracy beserta kelompoknya sebagai bahaya atau ancaman bagi kekaisarannya memakai istilah ideologie, dalam arti negatif, untuk menyifatkan filsuf mana saja bersama dengan simpatisan republik, dan lebihlebih kelompok Destutt de Tracy. Destutt de Tracy kemudian menggunakan istilah ideologie atau ideologi sebagai nama cabang filsafat tertentu itu.

Pandangan tentang ideologi sejak saat itu menjadi bersifat peyoratif, bergeser dari arti orisinalnya selaku science of ideas. Pandangan negatif mengenai ideologi tersebut lebih lanjut diterima dan bahkan dilanjutkan oleh Karl Marx yang menganggap ideologi sebagai kesadaran palsu mengenai kenyataan-kenyataan sosial ekonomi dan merupakan angan-angan kolektif diperbuat atau ditanggung bersama oleh kelas sosial tertentu. Melalui ideologi itulah proses riil dalam kehidupan masyarakat dibuat kabur. Dalam pandangan Marx, realitas merupakan alternatif terhadap ideologi atau dengan kata lain, ideologi terletak dalam oposisinya terhadap realitas. $^{12}$

Perhatian kepada konsep ideologi menjadi berkembang lagi karena pengaruh pemikiran Karl Marx tersebut. Ideologi menjadi vokabular penting di dalam pemikiran politik maupun ekonomi Karl Marx yang mengartikan ideologi sebagai pandangan hidup yang dikembangkan berdasarkan kepentingan golongan atau kelas sosial tertentu dalam bidang politik dan ekonomi. Dalam arti ini, ideologi menjadi bagian dari "uberbau" atau suprastruktur (bangunan atas) yang didirikan di atas kekuatankekuatan yang memiliki faktor-faktor produksi yang menentukan coraknya dan oleh karenanya mencerminkan suatu pola ekonomi tertentu. Kadar kebenarannya pun menjadi relatif dan semata-mata hanya untuk golongan tertentu. Ideologi, dengan demikian merupakan keseluruhan ide yang relatif, karena itu mencerminkan kekuatan

\footnotetext{
${ }^{11}$ Kaelan.

12 Slamet Sutrisno, Filsafat Dan Ideologi Pancasila (Yogyakarta: Andi, 2006).
} 
lapisan tertentu. ${ }^{13}$

Istilah ideologi, dalam penggunaan modern mempunyai arti yang negatif atau jelek yaitu sebagai teorisasi atau spekulasi dogmatik yang tidak betul atau tidak realistis, bahkan palsu dan menutup-nutupi realitas yang sesungguhnya. Dalam arti melioratif, ideologi adalah setiap sistem gagasan yang mempelajari keyakinankeyakinan dan hal-hal ideal, filosofis, ekonomis, politis, dan social. ${ }^{14}$ Sigmund Freud juga mengajukan rumusan ideologi sebagai suatu ilusi yang memperdaya dan menyudutkan manusia. Pendapat tersebut mempunyai latar belakang pada asumsi Freudian bahwa keyakinan manusia pada umumnya hanya merupakan khayalan belaka, yang bertolak dari distorsi atau represi terhadap kebutuhan-kebutuhan psikologis. $^{15}$

Berdasarkan uraian singkat di atas, dapat dilihat bahwa titik balik pemahaman terhadap istilah ideologi bermula pada pemikiran Karl Marx yang menganggap bahwa ideologi adalah kontra realitas sosial dan politik. Semenjak saat itu, ideologi pun dipahami dengan cara-cara yang berbeda oleh para filsuf. Ideologi bukan lagi merupakan science of ideas sebagaimana dikemukakan oleh Destutt de Tracy, tetapi sudah menjadi multi-makna. Masing-masing pemikir memiliki pemahaman yang berbeda-beda tentangnya. Berbagai macam pandangan tentang ideologi ini akan diuraikan dalam pembahasan berikutnya, yakni pengertian ideologi dari sudut pandang terminologis.

Sudut pandang ketiga, adalah sudut pandang terminologis. Pengertian ideologi secara terminologis, maksudnya adalah pengertian ideologi sebagai sebuah istilah yang dipahami, ditafsirkan, dimaknai, dan didefinisikan dengan cara yang bermacammacam oleh berbagai pemikir. Masing-masing pemikir memiliki sudut pandang mereka masing-masing di dalam memahami ideologi, sesuai dengan latar belakang filsafat yang mereka bangun atau mereka jadikan sebagai dasar pijakan berpikir. Oleh karena latar belakang pemikiran yang berbeda inilah ideologi kemudian dipahami dengan cara yang bermacam-macam.

Destutt de Tracy, sebagaimana telah dikemukakan di atas, memperkenalkan istilah ideologiste untuk mencirikan filsuf, yang seperti dirinya sendiri,

\footnotetext{
${ }^{13}$ Kaelan, Negara Kebangsaan Pancasila: Historis, Kultural, Filosofis, Yuridis, Dan Aktualisasinya.

${ }^{14}$ Bagus, Kamus Filsafat.

${ }^{15}$ Sutrisno, Filsafat Dan Ideologi Pancasila.
} 
mengembalikan ide-ide kepada kesan-kesan tempat asal ide-ide. Napoleon, yang menganggap Destutt de Tracy beserta kelompoknya sebagai bahaya atau ancaman bagi kekaisarannya memakai istilah ideologie, dalam arti negatif, untuk menyifatkan filsuf mana saja bersama dengan simpatisan republik, dan lebih-lebih kelompok Destutt de Tracy. Destutt de Tracy kemudian menggunakan istilah ideologie atau ideologi sebagai nama cabang filsafat tertentu itu. ${ }^{16}$

Karl Marx dan Engels menggunakan istilah ideologi untuk mengacu pada seperangkat keyakinan yang disajikan sebagai objek, padahal sebenarnya tidak lain dan tidak bukan hanya mencerminkan kondisi-kondisi material masyarakat. ${ }^{17}$ Ideologi, dalam pemikiran Karl Marx menjadi suprastruktur atau bangunan atas yang didirikan di atas kekuatan-kekuatan yang memiliki faktor-faktor produksi yang menentukan coraknya dan oleh karena itu mencerminkan suatu pola ekonomi tertentu. $^{18}$

Antonio Gramsci, salah seorang pemikir abad kontemporer juga memberikan pandangannya tentang ideologi. Gramsci menolak konotasi negatif ideologi meskipun ia sendiri sangat dipengaruhi oleh pemikiran Karl Marx. Gramsci memilahkan pengertian ideologi ke dalam term ideologi yang bersifat arbitrer dan ideologi yang bersifat organis. Hanya pada ideologi jenis pertama, yang arbitrer, memungkinkan adanya kesadaran palsu, sedangkan pada pengertian ideologi yang kedua, yang organis, tidak mungkin. Menurut Gramsci, ideologi organis ini bersifat netral sebagai suatu konsepsi tentang dunia yang secara implisit dimanifestasikan ke dalam kesenian, hukum, kegiatan ekonomi, dan semua manifestasi individual, maupun kolektif. ${ }^{19}$

C.A. van Peursen seorang pemikir dalam bidang budaya juga mengemukakan pendapatnya tentang ideologi. Menurutnya, ideologi dalam pengertian luas adalah seperangkat ide yang mengarahkan. ${ }^{20}$ Definisi ini memang cukup sulit dipahami karena bersifat abstrak. Hal ini disebabkan karena Van Peursen mendefinisikan ideologi secara normatif. Ideologi dalam pemahamannya merupakan seperangkat gagasan yang memiliki pengaruh besar dalam kehidupan manusia karena ia mampu mengarahkan, atau menggerakkan dinamika manusia ke arah idealisme yang telah

\footnotetext{
${ }^{16}$ Bagus, Kamus Filsafat.

${ }^{17}$ Bagus.

${ }^{18}$ Kaelan, Negara Kebangsaan Pancasila: Historis, Kultural, Filosofis, Yuridis, Dan Aktualisasinya.

${ }^{19}$ Sutrisno, Filsafat Dan Ideologi Pancasila.

${ }^{20}$ Sutrisno.
} 
dicita-citakan.

Selain para pemikir Barat, banyak juga pemikir Indonesia yang menaruh perhatian pada persoalan ideologi. Sutan Takdir Alisjahbana, menyatakan bahwa ideologi akhirnya akan berupa sistem nilai yang mungkin saya berdasar atas suatu weltanschauung. Ignas Kleden, merumuskan ideologi sebagai seperangkat doktrin sistematis tentang hubungan manusia dengan dunia hidupnya, yang diajarkan dan disebarluaskan dengan penuh kesadaran, yang tidak hanya memberikan suatu kerangka pengetahuan yang bersifat netral, tetapi yang meminta sifat dan komitmen dari pihak yang menerimanya, dan yang sedikit banyak menimbulkan moral passion dalam diri penganutnya. ${ }^{21}$

Kaelan, dalam Negara Kebangsaan Pancasila juga memberikan penafsiran tentang ideologi. Menurut Kaelan, seperti halnya filsafat, ideologi memiliki pengertian yang berbeda-beda. Pengertian yang berbeda-beda tersebut tergantung dari filsafat yang dianut karena sesungguhnya ideologi itu bersumber kepada suatu filsafat. Pengertian ideologi secara umum dapat dikatakan sebagai kumpulan gagasan-gagasan, ide-ide, keyakinan-keyakinan, kepercayaan-kepercayaan yang menyeluruh dan sistematis, yang menyangkut dan mengatur tingkah laku sekelompok manusia tertentu dalam pelbagai kehidupan. Hal ini menyangkut: bidang politik; bidang sosial; bidang kebudayaan; dan bidang keagamaan. ${ }^{22}$

\section{Hakikat Ideologi sebagai Ramalan Masa Depan}

Karl Mannheim adalah seorang filsuf dan sosiolog yang hidup pada akhir abad ke-19 hingga awal abad ke-20. Bicara tentang rentangan periode ini dalam sejarah filsafat, maka dapat ditemukan banyak tokoh besar dalam periode ini. Karl Marx (1818-1883) tentu adalah tokoh penting di abad tersebut yang dalam banyak hal mempengaruhi pemikiran Karl Mannheim. Sosiologi pengetahuan, sebagai bidang kajian baru dalam bidang sosiologi dan epistemologi, yang diperkenalkannya dapat dikatakan merupakan hasil dari pergulatan Karl Mannheim dengan sosiologi dan pandangan tentang realitas sosial masyarakat yang diperkenalkan oleh Karl Marx. Pandangan Karl Mannheim tentang ideologi dan utopia, juga banyak dipengaruhi oleh

\footnotetext{
${ }^{21}$ Sutrisno.

${ }^{22}$ Kaelan, Negara Kebangsaan Pancasila: Historis, Kultural, Filosofis, Yuridis, Dan Aktualisasinya.
} 
gagasan Karl Marx tersebut. Sikap Mannheim terhadap pemikiran Marx ini salah satunya dapat dilihat ketika Mannheim menyetujui pemahaman Marx dan tradisi Marxis tentang ideologi sebagaimana ditunjukkan dalam bukunya sebagai berikut.

Dalam pertentangannya dengan lawan borjuisnya, Marxisme sekali lagi menemukan bahwa di dalam soal-soal historis dan politis tak mungkin ada "teori murni". Marxisme melihat bahwa di balik setiap teori terdapatlah sudut pandang kolektif. Fenomena pikiran kolektif yang berlangsung menurut kepentingankepentingan dan situasi-situasi sosial dan eksistensial oleh Marx disebut dengan ideologi. Sosiologi pengetahuan yang diperkenalkan oleh Mannheim berpijak pada satu tesis utama, yaitu bahwa setiap pengetahuan manusia pasti berkaitan dengan eksistensinya, yang apabila dibawa kepada pemahaman yang lebih luas, sangat berkaitan dengan kedudukan manusia dalam masyarakat. Tesis ini, sangat dipengaruhi oleh gagasan Marx sebagaimana terlihat dalam kutipan di atas.

Paul Ricoeur dalam esainya tentang Mannheim yang kemudian dirangkum ke dalam sebuah buku dengan judul Lectures on Ideology and Utopia (1986) menulis bahwa pemikiran Mannheim tentang ideologi tidak dapat dilepaskan dari pemikiran Marx tentang hal yang sama. ${ }^{23}$ Menurut Ricoeur, dalam mengemukakan pemikirannya tentang ideologi, Mannheim berusaha memperluas gagasan atau konsepsi Marx tentang ideologi, meskipun pada akhirnya membawa kepada pemahaman yang membingungkan tentang ideology. ${ }^{24}$ Karl Marx, dalam kaitannya dengan ideologi, mengemukakan bahwa ideologi mengacu pada seperangkat keyakinan yang disajikan sebagai objek, padahal sebenarnya tidak lain dan tidak bukan hanya mencerminkan kondisi-kondisi material masyarakat. ${ }^{25}$ Ideologi, dalam pemikiran Karl Marx menjadi suprastruktur atau bangunan atas yang didirikan di atas kekuatan-kekuatan yang memiliki faktor-faktor produksi yang menentukan coraknya dan oleh karena itu mencerminkan suatu pola ekonomi tertentu. ${ }^{26}$

Bertolak dari gagasan Karl Marx tersebut, Mannheim kemudian mengembangkan pemahamannya tentang ideologi dengan melihat realitas adanya hubungan atau perpaduan antara dunia politik dengan pemikiran ilmiah. Karl

\footnotetext{
${ }^{23}$ Paul Ricoeur, Taylor, George H., Lectures on Ideology and Utopia (New York: Columbia University Press, 1986).

${ }^{24}$ Ricoeur, Taylor, George H.,.

25 Bagus, Kamus Filsafat.

${ }^{26}$ Kaelan, Negara Kebangsaan Pancasila: Historis, Kultural, Filosofis, Yuridis, Dan Aktualisasinya.
} 
Mannheim menggunakan istilah ideologi untuk menunjuk kepada seperangkat kepercayaan yang di dalamnya terdapat perbedaan-perbedaan motif-motif yang terungkapkan dan yang mendasari perilaku individu. ${ }^{27}$ Pada titik ini, Karl Mannheim berbeda dengan Marx. Mannheim berusaha mengeliminasikan elemen negatif ideologi dengan mengajukan konsepsi ideologi total dan ideologi partikular. Ideologi total merupakan ciri khas menyangkut struktur pikiran abad dan kelompok tertentu, misalnya sekelompok kelas sosial. Dalam hal ini ideologi berhimpit dengan weltanschauung yang didukung oleh struktur kolektif masyarakat. Berbeda dengan konsepsi total ideologi tersebut, ideologi partikular menghuni benak dan diterima secara psikologis oleh warga masyarakat. ${ }^{28}$

Karl Mannheim dan Karl Marx mungkin memiliki pemikiran yang berbeda tentang ideologi, namun demikian apabila ditarik generalisasi di antara keduanya, sebenarnya ada kesamaan yang ada dalam pemikiran kedua tokoh tersebut, yaitu bahwa keduanya memahami ideologi sebagai hal yang tidak dapat dilepaskan dari struktur kognitif manusia. Artinya, ideologi ada di ranah epistemologis, yaitu ranah pemikiran ilmiah. Selain itu, Mannheim juga sepakat dengan pendapat Marx bahwa pengetahuan tidak dapat dilepaskan dari eksistensi manusia, baik sebagai individu maupun sebagai anggota masyarakat. Pengetahuan oleh karenanya bersifat relasional, artinya memiliki hubungan yang erat dengan banyak faktor, dan tidak hanya berhubungan dengan kebenaran saja.

Selain Karl Marx, tokoh lain yang mempengaruhi pemikiran Karl Mannheim adalah Georg Simmel. Dalam konteks ini, dapatlah dikatakan bahwa Simmel-lah yang "membawa" Mannheim ke ranah filsafat karena seperti halnya Mannheim, Georg Simmel adalah sosiolog yang sekaligus seorang filsuf. Georg Simmel, adalah seorang sosiolog dan filsuf yang berasal dari Jerman. Dalam ilmu-ilmu sosial, Simmel dikenal sebagai seorang sosiolog, namun dalam bidang filsafat, ia dikenal sebagai seorang filsuf kebudayaan. Simmel lahir pada tahun 1858 dan meninggal dunia pada tahun 1918. Pertemuan Karl Mannheim dengan Simmel terjadi ketika Mannheim berpindah ke Jerman pada tahun 1919.

\footnotetext{
${ }^{27}$ Bagus, Kamus Filsafat.

${ }^{28}$ Sutrisno, Filsafat Dan Ideologi Pancasila.
} 
Sebagai seorang filsuf, Georg Simmel adalah seorang filsuf Neo-Kantian yang "menggunakan" metode Immanuel Kant ke dalam ranah yang baru, khususnya ranah ilmu-ilmu sosial. Jika Kant banyak menganalisis persoalan-persoalan ilmu kealaman, Simmel menggunakan metode Kant untuk menganalisis persoalan-persoalan sosiologi. Salah satu contohnya adalah ketika "mengubah" pernyataan Kant ketika menyelidiki tentang alam, yaitu: "What is nature?"; yang ia ubah dengan "What is society?". Salah satu gagasan Simmel yang barangkali menjadi gagasan kunci dalam pemikirannya adalah gagasannya bahwa kebudayaan merupakan "the cultivation of individuals through the agency of external forms which have been objectified in the course of history". ${ }^{29}$ Pemikiran Simmel inilah yang juga mempengaruhi pandangan Karl Mannheim tentang relasi antara pengetahuan dengan eksistensi individu, yang dalam banyak hal sangat dipengaruhi oleh banyak faktor, termasuk di dalamnya masyarakat atau komunitas.

Karl Marx dan Georg Simmel: setidaknya dua tokoh inilah yang mempengaruhi pemikiran Karl Mannheim tentang ideologi. Melihat pemikiran kedua tokoh tersebut, memang terlihat bahwa Karl Marx-lah yang banyak memberikan pengaruh kepada Karl Mannheim, khususnya dalam pemikirannya tentang relasi antara epistemologi dengan masyarakat. Georg Simmel, namun demikian juga tokoh yang tidak dapat diabaikan dalam kehidupan Karl Mannheim karena Simmel adalah sosiolog yang “membantu” Mannheim untuk menyeberangi jarak antara sosiologi dan filsafat dengan sebuah kajian yang dinamai sosiologi pengetahuan.

Pemikiran Karl Mannheim tentang ideologi, dapat dijumpai salah satunya dalam bagian kedua dari bukunya, Ideology and Utopia, An Introduction to the Sociology of Knowledge. Buku ini telah diterjemahkan ke dalam bahasa Indonesia oleh F. Budi Hardiman pada tahun 1991. Guna memudahkan pemahaman tentang karya Mannheim, peneliti menggunakan buku ini sebagai referensi utama.

Penyelidikan terhadap pemikiran Karl Mannheim tentang ideologi, tidak dapat dipisahkan dari penjelasannya terhadap istilah yang menjadi "pasangannya", yaitu utopia. Selain itu, ada hal lain yang juga perlu diingat dalam hal pembedaan ideologi menurut Mannheim. Penjelasan tentang ideologi dalam pandangan Mannheim ini, oleh

\footnotetext{
${ }^{29}$ Georg Simmel, Georg Simmel on Individuality and Social Forms, ed. Donald N. Levine (Chicago: University of Chicago Press, 1971).
} 
karenanya akan dibagi ke dalam dua pembahasan besar tersebut, yaitu pembedaan ideologi dan utopia, serta pembedaan dua jenis ideologi: total dan partikular.

Karl Mannheim, meskipun pada dasarnya adalah seorang sosiolog, namun demikian ketika menfasirkan istilah ideologi, ia melihat adanya realitas bahwa sedikit banyak ada campur tangan politik di dalam dialektika pemahaman sebuah ideologi. Menurutnya, konsep "ideologi" mencerminkan satu penemuan yang timbul dari konflik politis, yaitu ketika pikiran kelompok-kelompok yang berkuasa sudah terbelenggu ke dalam kepentingan atau situasi-situasi tertentu sehingga mereka tidak dapat lagi melihat fakta secara jernih. Di dalam kata "ideologi" implisit terdapat penerangan bahwa dalam situasi-situasi tertentu, ketidaksadaran kolektif kelompokkelompok tertentu menggelapkan kondisi real dari suatu masyarakat, baik bagi diri mereka sendiri, maupun bagi kelompok-kelompok lain dan dengan jalan itu menstabilkan kondisi masyarakat itu. ${ }^{30}$

Berdasarkan kutipan tersebut, dapatlah disimpulkan bahwa dalam pandangan Mannheim, istilah ideologi selalu mengandung di dalamnya sebuah distorsi, yaitu distorsi atas realitas yang tertutupi akibat dari adanya ketaksadaran kolektif masyarakat tadi. Pada kondisi yang ekstrim, ideologi dapat berarti keadaan yang sama sekali bertentangan dengan kenyataan yang senyatanya ada, yakni ketika distorsi terhadap realitas tersebut terjadi dengan sedemikian besarnya. Pemahaman Mannheim tentang ideologi ini kemudian bertalian erat dengan utopia. Jika distorsi dalam ideologi tadi muncul karena adanya ketaksadaran kolektif yang kemudian menutupi kenyataan yang ada, utopia oleh Mannheim digunakan untuk menyebut sebuah kondisi ketika terjadi kesalahan pemahaman masyarakat atau suatu kelompok terhadap realitas akibat dari adanya ketertindasan secara intelektual.

Konsep pemikiran "utopis" mencerminkan penemuan yang berlawanan dari perjuangan politis, yaitu bahwa kelompok-kelompok tertentu yang tertindas secara intelektual sedemikian kuatnya berkepentingan untuk menghancurkan dan mengubah kondisi masyarakat yang ada sehingga mereka mau tak mau hanya melihat unsur-unsur yang cenderung menolak kondisi tersebut dalam situasi tersebut. Pikiran mereka tidak mampu mendiagnosis kondisi masyarakat yang ada secara tepat. Mereka tidak

\footnotetext{
${ }^{30}$ Karl Mannheim, Ideologi Dan Utopia: Menyingkap Kaitan Pikiran Dan Politik, Terjemahan (Yogyakarta: Kanisius, 1991).
} 
memusatkan diri pada apa yang sesungguhnya ada, melainkan dalam pikiran mereka, mereka sudah berusaha untuk mengubah situasi yang ada. ${ }^{31}$

Ideologi dan utopia, dalam pandangan Mannheim sebetulnya menyiratkan satu hal yang sama, yaitu kontradiksi antara pemikiran dengan kenyataan. Keduanya samasama merujuk pada satu kondisi yang belum atau tidak terjadi. Pertanyaan yang kemudian muncul, tentu adalah sebagai berikut: lantas, apa perbedaan antara ideologi dan utopia? Arief Budiman, dalam pengantar terjemahan buku Mannheim tersebut, mengatakan bahwa ideologi dan utopia memiliki perbedaan dalam hal kemungkinannya menjadi realitas berdasarkan sistem yang telah ada pada saat ini. Inilah pikiran baru dari Mannheim, ideologi berarti ramalan tentang masa depan yang didasarkan pada sistem yang sekarang sedang berlaku, sedangkan utopia berarti ramalan tentang masa depan yang didasarkan pada sistem lain, yang pada saat ini tidak sedang berlangsung. Karena itu, semua kemungkinan perubahan sebuah masyarakat yang tidak didasarkan pada sistem yang ada dianggap sebagai sesuatu yang utopis. ${ }^{32}$

Satu hal lain, yang perlu dikaji dalam kaitannya dengan pandangan Mannheim tentang ideologi adalah soal istilah ideologi itu sendiri. Pada bagian yang bertajuk “ideologi dan utopia” tersebut, Mannhein menyinggung peran tradisi Marxisme dalam pemahaman terhadap istilah ideologi. Pembahasan tentang riwayat hidup dan pemikiran Karl Mannheim menyebutkan bahwa pemikiran Mannheim tentang ideologi memang banyak dipengaruhi oleh pemahaman ideologi dalam tradisi Marxis. Meski demikian, dalam pembahasannya tentang ideologi, Mannheim menegaskan bahwa pemahaman tentang ideologi dapat dilacak, jauh sebelum tradisi Marxis tersebut muncul. Mannheim bahkan menyebutkan bahwa pemahaman tentang ideologi ini kadang-kadang mengalami penambahan dan pembentukan baru.

Bagi kebanyakan orang, istilah "ideologi" erat terkait dengan Marxisme dan reaksi-reaksi mereka terhadap istilah itu sebagian besar ditentukan oleh kaitan itu. Oleh karena itu pertama-tama perlulah menegaskan bahwa meskipun Marxisme menyumbang pernyataan asli masalah ideologi, baik kata maupun artinya, dalam sejarahnya dapat ditelusuri lebih jauh daripada Marxisme, dan kadang kala pengertianpengertian baru dari kata itu muncul, terbentuk secara independen dari Marxisme. ${ }^{33}$

\footnotetext{
${ }^{31}$ Mannheim.

${ }^{32}$ Mannheim.

${ }^{33}$ Mannheim.
} 
Terlepas dari peran tradisi Marxis di dalam memperjelas makna ideologi tersebut, Mannheim kemudian mengemukakan bahwa di dalam memahami ideologi, harus dibedakan dua macam ideologi, yaitu ideologi dalam arti partikular dan ideologi dalam arti total. Konsep partikular dari istilah ideologi muncul ketika di dalam sebuah komunikasi yang melibatkan dua pihak, salah satu pihak meragukan atau menyangsikan gagasan dan penjelasan yang dikemukakan oleh pihak yang lain. Keraguan ini muncul karena satu pihak merasa bahwa pihak yang lain telah menyembunyikan hakikat kenyataan yang sesungguhnya karena kenyataan tersebut tidak sesuai dengan kepentingan lawan bicaranya. Mannheim menyebut ini dengan distorsi.

Distorsi-distorsi ini mencakup segala cara dari penipuan-penipuan secara sadar sampai pengelabuan-pengelabuan setengah sadar dan sama sekali tak diketahui; dari upaya-upaya yang diperhitungkan sampai membuat orang lain menipu dirinya. ${ }^{34}$ Berbeda dengan ideologi partikular, ideologi total berkaitan dengan ideologi suatu kelompok sosio-historis konkret, misalnya ideologi kelas. ${ }^{35}$ Berdasarkan uraian tersebut dapatlah dikatakan bahwa ideologi partikular dan ideologi total memiliki perbedaan yang signifikan. Ideologi total merupakan ciri khas menyangkut struktur pikiran abad dan kelompok tertentu, misalnya sekelompok kelas sosial. Dalam hal ini ideologi berhimpit dengan weltanschauung yang didukung oleh struktur kolektif masyarakat. Berbeda dengan konsepsi total ideologi tersebut, ideologi partikular lebih menghuni benak dan diterima secara psikologis oleh warga masyarakat. ${ }^{36}$

Inilah uraian singkat pandangan Karl Mannheim tentang ideologi. Berdasarkan uraian di atas, dapatlah disimpulkan bahwa ideologi dalam pandangan Mannheim, mengacu pada sebuah kondisi yang belum atau tidak terjadi, dalam arti tidak ada dalam kenyataan. Ideologi berarti ramalan tentang masa depan berdasarkan pada sistem yang saat ini sedang berlaku. Selain itu, Mannheim juga membedakan dua macam ideologi, yaitu ideologi partikular dan ideologi total. Ideologi partikular adalah ideologi yang dipahami secara psikologis oleh seorang individu; sedangkan ideologi total adalah ideologi yang dimiliki oleh suatu komunitas sehingga sangat dekat dengan pengertian welstanchauung.

\footnotetext{
${ }^{34}$ Mannheim.

${ }^{35}$ Mannheim.

${ }^{36}$ Sutrisno, Filsafat Dan Ideologi Pancasila.
} 


\section{Landasan Filosofis Ideologi}

Sebuah ideologi pada hakikatnya adalah sebuah pemikiran yang didasari oleh berbagai asumsi filosofis. Asumsi-asumsi tersebut mendasari berbagai macam pemikiran karena asumsi filosofis bersifat umum, dalam arti mendasari segala macam pemikiran. Atau dengan kata lain, di dalam setiap pemikiran apapun, disadari atau tidak, tersembunyi asumsi filosofis yang menjadi dasar pemikiran tersebut. Hal yang sama juga terjadi dalam sebuah pemikiran ideologi tertentu. Sebagaimana dikemukakan oleh Kaelan, ideologi memiliki hubungan yang erat dengan filsafat.

Filsafat sebagaimana pandangan hidup, pada hakikatnya merupakan sistem nilai yang secara epistemologis kebenarannya telah diyakini sehingga dijadikan dasar atau pedoman bagi manusia dalam memandang realitas, alam semesta, manusia, masyarakat, bangsa, dan negara, tentang makna hidup sebagai pedoman bagi manusia dalam menyelesaikan masalah yang dihadapi dalam hidup dan kehidupan. Tiap ideologi sebagai suatu rangkaian kesatuan cita-cita yang mendasar dan menyeluruh yang jalin menjalin menjadi suatu sistem pemikiran yang logis, adalah bersumber kepada filsafat. Ideologi, dengan kata lain mencari nilai-nilai, norma, dan cita-cita yang bersumber pada filsafat yang bersifat mendasar dan nyata untuk diaktualisasikan.

Berdasarkan pendapat Kaelan di atas, kiranya menjadi penting untuk menganalisis suatu ideologi dari sudut pandang filosofis, dalam arti menggali asumsiasumsi filosofis yang mendasari ideologi tersebut, agar hakikat pemikiran dalam ideologi tersebut dapat dipahami dengan lebih baik. Asumsi-asumsi filosofis tersebut terdiri atas asumsi atau landasan ontologis, landasan epistemologis, dan landasan aksiologis. Asumsi-asumsi filosofis inilah yang akan dicari di dalam pemikiran Mannheim tentang ideologi.

Landasan ontologis atau landasan metafisik, adalah landasan yang berkaitan dengan asumsi suatu ideologi terhadap realitas. Dalam pemikiran Karl Mannheim, pemikiran ontologis ini dapat dilihat dalam asumsi Mannheim tentang realitas. Pertama, sesuai dengan karakternya sebagai Neo-Kantian, Mannheim sebenarnya percaya pada satu realitas yang ada pada dirinya sendiri. Dalam pemikiran Kant, ini disebut dengan realitas objektif, yaitu das ding an-sich atau "objek dalam dirinya sendiri”. Hal ini dapat dilihat dalam penjelasan Mannheim tentang adanya distorsi di dalam ideologi. Di dalam istilah distorsi, terkandung asumsi bahwa ada pesan yang 
ingin disampaikan, atau ada kenyataan yang senyatanya ada, namun kenyataan ini tidak mampu ditangkap dengan benar. Hal ini menunjukkan bahwa Mannheim percaya adanya realitas objektif yang keberadaannya sebenarnya tidak terpengaruh oleh manusia sebagai subjek yang mencerapnya.

Kedua, adalah landasan epistemologis. Landasan epistemologis adalah landasan yang berkaitan dengan asumsi suatu ideologi terhadap cara mengetahui realitas. Dalam pemikiran Mannheim, hal ini dapat dilihat dari pemikirannya bahwa pengetahuan erat berkaitan dengan eksistensi manusia. Meskipun secara ontologis Mannheim percaya adanya kebenaran objektif, namun Mannheim menunjukkan sikap subjektifnya dalam bidang epistemologis. Yaitu bahwa kebenaran sangat dipengaruhi oleh eksistensi seorang manusia, baik dalam kedudukannya sebagai individu, maupun dalam kedudukannya sebagai anggota masyarakat.

Ketiga, adalah landasan aksiologis, yaitu landasan yang berkaitan dengan asumsi suatu ideologi terhadap nilai. Dalam sistematika filsafat, pandangan aksiologi ini sebenarnya sangat berkaitan erat dengan pandangan ontologi dan epistemologi yang dimiliki. Secara ontologis, Mannheim mengasumsikan adanya kenyataan objektif; sedangkan secara epistemologis, Mannheim menyiratkan pandangan subjektivisme pengetahuan. Kedua hal ini sebenarnya kontradiktif, namun demikian bagi peneliti hal ini dapat dijelaskan kaitannya dengan politik. Pada pembahasan sebelumnya telah dikatakan bahwa aspek politik memiliki pengaruh yang kuat dalam konsepsi ideologi. Kekuasaan dengan kata lain masih menjadi nilai utama dalam hierarkhi nilai menurut Mannheim. Kekuasaan dan kepentingan ini pula yang menyebabkan adanya distorsi di dalam komunikasi dua pihak sehingga mengakibatkan tidak dipahaminya kenyataan atau realitas secara baik.

\section{SIMPULAN}

Karl Mannheim adalah seorang filsuf yang juga menjadi pelopor lahirnya bidang kajian sosiologi pengetahuan. Oleh karenanya, membahas pemikiran Mannheim tentang ideologi tanpa membahas pemikirannya tentang masyarakat dan proses epistemik yang terjadi di dalam masyarakat, kiranya merupakan satu persoalan yang serius. Berdasarkan penelitian yang telah dilakukan, dapat disimpulkan beberapa hal sebagai berikut. Menurut Karl Mannheim, ideologi mengacu pada sebuah kondisi yang belum atau tidak terjadi, 
dalam arti tidak ada dalam kenyataan. Ideologi berarti ramalan tentang masa depan berdasarkan pada sistem yang saat ini sedang berlaku. Selain itu, Mannheim juga membedakan dua macam ideologi, yaitu ideologi partikular dan ideologi total. Ideologi partikular adalah ideologi yang dipahami secara psikologis oleh seorang individu; sedangkan ideologi total adalah ideologi yang dimiliki oleh suatu komunitas sehingga sangat dekat dengan pengertian welstanchauung. Dari perspektif ontologis, dalam pemikiran Karl Mannheim tentang ideologi terkandung asumsi adanya realitas objektif. Dari perspektif epistemologi, pemikrian Karl Mannheim tentang ideologi menyiratkan pemikiran subjektivisme epistemologis. Dari perspektif aksiologis, kekuasaan yang berkaitan dengan politik masih menduduki hierarki yang tertinggi dalam ideologi.

\section{DAFTAR PUSTAKA}

Ackroyd, S. "Utopia or Ideology: Karl Mannheim and the Place of Theory." The Sociological Review. journals.sagepub.com, 2002. https://doi.org/10.1111/j.1467954X.2002.tb03578.x.

Bagus, Lorens. Kamus Filsafat. Jakarta: Gramedia Pustaka Utama, 2000.

Darity, William A. "International Encyclopedia of the Social Sciences.” Detroit, Mich.: Macmillan Reference USA, 2008. http://go.galegroup.com/ps/infomark.do?action=interpret\&id=GALE\%7C1RIY\&v $=2.1 \& \mathrm{it}=$ aboutBook\&source=null\&p=GVRL\&authCount $=1$.

Fuchs, Christian. Nationalism on the Internet. Routledge, 2019. https://doi.org/10.4324/9780429343476.

Griffith, Malcolm, Earl Seidman, and Marshall McLuhan. "Understanding Media: The Extensions of Man." College Composition and Communication, 1968. https://doi.org/10.2307/355246.

Kaelan. Negara Kebangsaan Pancasila: Historis, Kultural, Filosofis, Yuridis, Dan Aktualisasinya. Yogyakarta: Paradigma, 2013.

MacKinnon, Rebecca. “The Netizen.” Development 55, no. 2 (June 7, 2012): 201-4. https://doi.org/10.1057/dev.2012.5.

Mannheim, Karl. Ideologi Dan Utopia: Menyingkap Kaitan Pikiran Dan Politik. Terjemahan. Yogyakarta: Kanisius, 1991.

Nuswantoro, and Amien Wangsitalaja. Daniel Bell: Matinya Ideologi. Magelang: Indonesia Tera, 2001. 
Ricoeur , Taylor, George H., Paul. Lectures on Ideology and Utopia. New York: Columbia University Press, 1986.

Simmel, Georg. Georg Simmel on Individuality and Social Forms. Edited by Donald N. Levine. Chicago: University of Chicago Press, 1971.

Sontag, Frederick. Problems of Metaphysics. Scranton, Chandler Pub. Co., 1970.

Sutrisno, Slamet. Filsafat Dan Ideologi Pancasila. Yogyakarta: Andi, 2006.

Tamdgidi, M H. "Ideology and Utopia in Karl Mannheim: Revisiting the Origins of the Sociology of Self-Knowledge for an Exploratory Framework." In Human Architecture: Journal of the Sociology of Self-Knowledge. Okcir Press, 2020. http://search.ebscohost.com/login.aspx?direct=true\%5C\&profile=ehost $\% 5 \mathrm{C} \&$ scop $\mathrm{e}=$ site $\% 5 \mathrm{C} \&$ authtype $=$ crawler\%5C $\& \mathrm{jrnl}=15405699 \% 5 \mathrm{C} \& \mathrm{AN}=146868737 \% 5 \mathrm{C} \&$ h=S4YD54vEJ8FxzzDk37CIHdzOcnyT7TU\%2FNkrC5wObVAGiF\%2FSLzSizi MOSJuhq6Y8NsNuRNTumnZgZYp\%2BvzVxI3w\%3D\%3D\%5C\&crl=c. 